\title{
SALOMÉ, A MUSA DO FIM-DO-SÉCULO
}

por Álvaro Cardoso Gomes ${ }^{1}$

\begin{abstract}
RESUMO: Tendo por base o poema "Salomé", da autoria de Mallarmé, o artigo analisa a personagem, procurando entendê-la como verdadeiro topus do fim-do-século, graças ao modo como ela aniquila o homem com seu erotismo gelado. Salomé, nesse sentido, é vista mais como um símbolo, a representação de uma época do que uma figura histórica ou mítica.
\end{abstract}

Palavras-Chave: Musa, Mulher fatal, Erotismo, Símbolo.

ABSTRACT: This article on Mallarmé's poem "Salomé" analyses the character as a fin de siècle topus because she destroys males with her cold eroticism. In this sense, Salomé is seen more as a symbol, as a representation of a period, rather than as an historical or mythical figure.

KEYWORDS: Muse, Femme fatale, Eroticism, Symbol.

Cada época tem sua musa de plantão. É o que Álvaro de Campos mostra ao longo de uma das estrofes de "Tabacaria":

Tu, que consolas, que não existes e por isso consolas,

Ou deusa grega, concebida como se fosse viva,

Ou patrícia romana, impossivelmente, nobre e nefasta,

Ou princesa de trovadores, gentilíssima e colorida,

Ou marquesa do século dezoito, decotada e longínqua,

Ou cocote célebre do tempo dos nossos pais,

Ou não sei quê moderno - não concebo bem o quê - (PESSOA, 1965, p. 364)

No Romantismo, parece que a musa assume pela primeira vez declaradamente a face da anima perversa, cujo expoente máximo é Cleópatra (e em alguns momentos, Helena), a devoradora de homens. Consubstanciando-se como a alma sombria do poeta, Cleópatra inverte as tradicionais posturas entre o homem e a mulher, ao submeter o macho a seus desígnios e ao se transformar num simulacro do caçador que persegue e mata a caça. Essa inversão dos papéis sexuais consagrados pela tradição e, sobretudo, pela moral cristã, talvez seja assumida por ela, devido a um processo de femininização do eu masculino que, ao se emascular, dá as prerrogativas da sexualidade ardente, do papel ativo à mulher. No final do século XIX, Cleópatra vai lentamente desaparecendo de cena e quem assume o papel de anima perversa é Salomé, mas por uma razão algo diversa da rainha egípcia. Na obra do ensaísta espanhol R. Cansino-Assens, essa diferença é assim explicada: "o segredo psíquico de Salomé se cifra em sua virgindade, e é isto que torna impossível compará-la com as representações míticas da Luxúria" (1918, p. 81). Salomé é a mulher fatal, cujo poder emana da virgindade que a atormenta e que provoca e destrói quem dela se aproxima. Mas o que representa essa figura de uma sexualidade gelada para a literatura finissecular? É o

\footnotetext{
${ }^{1}$ Professor titular de Literatura Portuguesa da USP, autor de A estética simbolista, A estética romântica, A Melodia do silêncio. É também romancista, autor de $O$ sonho da terra, Os rios inumeráveis, concerto amazônico, entre outros (contato: alcgomes@uol.com.br)
} 
que pretendo examinar, concentrando-me na análise da hermética incursão de Mallarmé ao universo saloméico em seu poema dramático "Herodiade".

Antes de tudo, é preciso considerar que há uma Salomé que a história perdeu para a legenda e que o "Velho Testamento" resgatou parcimoniosamente. Tanto o texto de Mateus quanto o de Marcos são muito concisos e não expõem os reais motivos de a dançarina núbil pedir como prêmio a cabeça do Precursor:

Festejando-se, porém o dia natalício de Herodes, dançou a filha de Herodias diante dele e agradou a Herodes, pelo que prometeu, com juramento dar-lhe tudo o que pedisse.

E ela, instruída previamente por sua mãe,

Disse: Dá-me aqui num prato a cabeça de João Batista.

E o rei afligiu-se, mas, por causa do juramento e dos que estavam à mesa com ele, ordenou que se lhe desse.

E mandou degolar João no cárcere, e a sua cabeça foi trazida num prato e dada à jovem, e ela a levou a sua mãe.(Mateus, 14)

Porquanto o mesmo Herodes mandara prender a João e encerrá-lo manietado no cárcere, por causa de Herodias; mulher de Filipe, seu irmão, porquanto tinha casado com ela.

Pois João dizia a Herodes: Não te é lícito possuir a mulher de teu irmão.

E Herodias o espiava e queria matá-lo, mas não podia; porque Herodes temia a João, sabendo que era varão justo e santo; e guardava-o com segurança e fazia muitas coisas, atendendo-o, e de boa vontade o ouvia.

E, chegando uma ocasião favorável em que Herodes, no dia do seu aniversário, dava uma ceia aos grandes, e tribunos, e príncipes da Galiléia, entrou a filha da mesma Herodias, e dançou, e agradou a Herodes e aos que estavam com ele à mesa. Disse, então, o rei à jovem: pede-me o que quiseres, e eu to darei.

E jurou-lhe, dizendo: Tudo o que me pedires te darei, até metade do meu reino.

E, saindo ela, perguntou à sua mãe: Que pedirei? E ela disse: A cabeça de João Batista.

E, entrando apressadamente, pediu ao rei, dizendo: Quero que, imediatamente, me dês num prato a cabeça de João Batista.

E o rei entristeceu-se muito; todavia, por causa do juramento e dos que estavam com ele à mesa, não lha quis negar.

$\mathrm{E}$, enviando logo o rei o executor, mandou que lhe trouxessem ali a cabeça de João. E ele foi e degolou-o na prisão.

E trouxe a cabeça num prato e deu-a à jovem, e esta a deu à sua mãe. (Marcos, 6)

Nos versículos bíblicos, Salomé é mero apêndice de Herodíade, esta sim, premeditando algo e utilizando-se dos encantos da filha para seduzir o caquético Herodes. Em realidade, há por detrás dos dois relatos uma trama moral e política: o Batista representa uma ameaça a Herodíade, porque ela lhe recrimina o incesto (ela é cunhada de Herodes que, por sua vez, assassinou o próprio irmão), os vícios, com isso, ameaçando seu poder e, de viés, o instável poder do régulo da Judéia. Salomé só se libertará da influência da mãe e adquirirá autonomia quando captada pela imaginação dos poetas e prosadores que lhe darão um estatuto todo próprio e a transformarão em estrela de primeira grandeza. Recordo imediatamente do poema dramático de Wilde, em que a figura de Herodíade se apaga e Salomé brilha. No texto, sua sensualidade tão represa só se escoará por meio de metáforas de sentido dúbio. O próprio discurso sensualiza-se, contaminando a fala do Precursor. João Batista, na visão de Wilde, 
torna-se um demente possuído por uma fúria sexual que, antifrasicamente, se traduz no ódio à sedutora. Mas há outras versões não menos famosas do mesmo mito: o conto de Flaubert, que atenta mais para o lado político do episódio, o conto surrealista de Laforgue, em que a androginia de Salomé assume seu ponto máximo de expressão, com os seios lembrando "amêndoas espetadas por um cravo da Índia", o decadente e especiosos poema de Eugénio de Castro, os poemas de Banville, Pierre Louÿs, Apollinaire, Samain, Fernando Pessoa, SáCarneiro, Alfredo-Pedro Guisado, Ruben Darío, entre muitos outros, além do célebre comentário que Des Esseintes, personagem de A rebours, de J.-K. Huysmans, faz sobre a personagem das telas simbolistas de Gustave Moreau "Salomé" e "Aparição".

Essas glosas dos textos bíblicos, ao realçarem a sexualidade e o desejo de satisfazer a angústia reprimida por uma sociedade castradora, acabam por sobrevalorizar Salomé, fazendo dela verdadeiro topus do fim-do-século: "mediante um ato de franca amoralidade, um crime espiritual ou físico", no dizer de Cansino-Assens, a dançarina transforma-se num ícone, num catalisador, num alter-ego de diferentes artistas que projetam nela a insatisfação ou a sensação de mal-estar experimentado pelo decadente mundo em que viviam (1918, p. 52). Mas é preciso considerar também que, em alguns textos, a sexualidade reprimida representa um anseio de espiritualidade. Isso acontece em parte no poema dramático de Eugénio de Castro e, de maneira mais explícita, na versão mascarada de Salomé levada a cabo por Mallarmé.

Mascarada porque Mallarmé nomeia a heroína de Herodíade, quando, em realidade, está tratando de Salomé. Herodíade, por razões óbvias, não era virgem e nem chegou a manifestar aguda paixão por João Batista. A subversão do mito realizada por Mallarmé seria uma espécie de "licença poética" em relação à imagem da dançarina: o poeta substitui o nome porque "Herodíade" é mais vantajoso poeticamente do que "Salomé". "Herodíade" pode ser decomposto em três segmentos: a) Ero(s) - princípio da ação, do desejo sexual; b) Dia (prefixo, do grego diá) - separação, através de; c) Diade (do grego dyas, ados, do latim, dyade - um par, grupo de dois.

Não é difícil de se perceber no erotismo gelado da Herodiade de Mallarmé a rejeição do próprio erotismo, o que implicaria que ela se realizasse contraditoriamente através de Eros/distanciada de Eros. O mesmo se dá com seu ser duplo, presente tanto na sua multiplicação por meio da figura da Ama e/ou de João Batista e da sua duplicação, por meio das constantes imagens especulares, tantas vezes reiteradas no texto. Essa duplicidade é que possibilitará inclusive a leitura metalingüística do drama mallarmaico - afinal, Mallarmé explorou habilmente uma das representações simbólicas de Salomé (com sua Herodiade): a do poeta decadente do final do século, que busca um absoluto espiritual, muito além da materialidade grosseira.

O poema ${ }^{2}$, composto de três partes, I. Abertura, II. Cena, III. Cântico de São João, oferece imensas dificuldades ao leitor, devido ao hermetismo, à cerrada cifra de metáforas e, sobretudo, ao fato de ser um projeto inacabado. Contudo, é possível assim mesmo detectar unidade nele e um sentido entre vários, desde que se consiga penetrar na duração criada por Mallarmé. O efeito da concentração máxima de efeitos abortaria, por exemplo, qualquer tentativa de uma decifração literal do texto ou de uma decifração dos símbolos vistos isoladamente. Em realidade, o leitor é chamado a colaborar, a preencher os vácuos de sentido com sua imaginação. É que Mallarmé defendia o princípio de que, em poesia, é fundamental o poder da "alusão", que propicia aos espíritos a "alegria deliciosa de acreditar que estão criando" (Apud GOMES, 1994, p. 102). Desse modo, é preciso antes de tudo compreender que o poema deve ser lido não como um conjunto de metáforas isoladas, mas, sim, como uma grande metáfora expandida, que confina no símbolo, assim entendido por Saint Antoine:

\footnotetext{
2 Todas as citações de "Salomé" provêm da tradução do poema levada a cabo por Augusto de Campos em Linguaviagem. São Paulo: Companhia das Letras, 1987.
} 
é prolongar ao máximo uma emoção. (...) Essa emoção prolongada pode nascer - com a ajuda do gênio do poeta - da simples expressão. Frequentemente, ela resultará da imagem; deste modo, a sensação que desperta será prolongada e reforçada por uma impressão de outro tipo; será por exemplo, uma emoção íntima refletida e univgersalizada na natureza ambiente ou, reciprocamente, um cenário exterior repentinamente animado pela paixão do poeta (Apud GOMES, 1994, p. 124-125).

Essa expansão do conceito de símbolo é que impede os vazios de significado e que instaura o princípio da musicalidade, tal como Mallarmé concebia. A reiteração das imagens que se prolongam ao máximo, ocasionando uma espécie de fuga e o retorno ao tema lembra em tudo o movimento musical que se perde para se reencontrar: "quando uma nova nota soa, a que a precedeu não desaparece sem um traço; de outra maneira, seríamos incapazes de observar as relações entre notas que s seguem às outras" (HUSSERL, 1964, p. 30). A imagem de Herodíade, nesse jogo, constitui um pólo aglutinador, desdobrado em imagens de outro tipo.

As três partes da obra concentram-se nas três figuras que a compõem: a primeira na Ama, a segunda em Herodíade, a terceira em João Batista. Herodíade é o centro irradiador de sentidos, desdobrado na Ama, de um lado, e em João Batista, no outro. Se adotarmos a terminologia jungueana dos arquétipos, poder-se-ia dizer que a Ama é a representação da persona, enquanto o Precursor é a representação do animus, a porção masculina da personagem. As três figuras, ao mesmo tempo em que se dispersam, acabam por se encontrar no final do poema, convergindo simbolicamente para a figura do poeta, criador desse mundo imaginário. O efeito da dispersão provocará o dinamismo propício à existência do drama, enquanto o efeito da concentração fará nascer o símbolo, concebido aqui não como um sinal unívoco (a exemplo da cruz e da bandeira), mas como um pólo irradiador de significados, capaz de se desenvolver e dar continuidade à emoção, prolongando-a ao máximo, mimetizando com isso a imagem da duração.

O poema tem impressionante coesão, na medida em que a fígura de Herodíade se multiplica em unidades de sentido dispersas pelo texto. A imagem "virgem exilada em sua pura imagem", que remete ao mito de Narciso, desdobra-se na comparação explícita "como um cisne que escondeu os olhos na plumagem", em "a água só reflete o exílio/Do outono que extinguiu no espelho o fogo e o brilho" e em "uma Aurora em lágrimas as alas!". Herodíade é, pois, Aurora, outono e cisne, emblemáticos, respectivamente, de um processo de extinção e de rejeição da realidade (a Aurora e o outono agonizam, e o cisne "esconde os olhos na plumagem" ou "por entre a lápide gelada/Ou a pluma afundou o colo").

A primeira parte do poema, em versos alexandrinos, constitui-se apenas no solilóquio da Ama que, solitária, realiza a abertura do drama com a chegada da aurora, perifrasicamente identificada a um pássaro: "eis que uma Aurora, heráldica plumagem, quis/Fazer de nossa torre cinerária o nicho". A imagem da torre, em que se encerram a Ama e Herodíade, é clichê simbolista, representando o isolamento da realidade. Ainda: na torre, a passagem do tempo se anula, pois que a construção mimetiza o espaço mortuário, o intervalo entre o crepúsculo e aurora, entre a vida e a morte, entre o real e o irreal: "ah, mausoléu de reinos tristes a findar". Além disso, a torre, por ser elevada, aproxima o ser da idealidade pura, o "diamante puro de uma estrela, a qual/Não cintilou jamais seu furor ancestral". A Ama cumpre, pois, o papel de Sibila, por abrir o poema e conter em si os germes do passado e do futuro. No primeiro caso, ela é "uma voz do passado em longo pensamento/É a minha, já prestes ao encantamento?"; no segundo caso, profetiza a morte do sonho, do ideal: 
Como os (olhos) pusera o velho cisne a pluma, vôo

Da pluma desconsolo no imortal revôo

De esperança por ver os diamantes finais

De uma estrela morrente e que não brilha mais.

A segunda parte do poema, também em alexandrinos, é mais dinâmica, porque a Ama agora dialoga com Herodíade - a conversa das duas é o pretexto para que, simbolicamente, se dê o confronto entre a realidade e a irrealidade. A Ama exerce aqui outro papel, o de mediador entre o real e o irreal, o que justifica sua identificação com o arquétipo jungueano da persona, enquanto Herodíade, sintomaticamente qualificada como "uma sombra de princesa", é a sombra, o ser que se distancia da materialidade e se detém a "sonhar nos exílios". Desse antagonismo, nascem um movimento de atração em relação à realidade e um movimento de rejeição dessa mesma realidade. A Ama diz: "cessa de caminhar para o ignoto", e Herodíade retruca: "que o louro rio de meus cabelos virgens flua/(...) Mulher, um beijo, e eu morreria". A recusa da realidade por parte de Herodíade terá como consequiência a virgindade, a esterilidade:

Os meus cabelos, que não são flores amenas

A difundir o olvido das humanas penas,

Mas ouro, para sempre virginal de olores,

Em seus clarões cruéis e pálidos fulgores,

Observam a frieza estéril do metal.

Herodíade, negando a sexualidade, tem como objetivo a negação do outro, e isso se verifica de modo mais evidente na tentativa de ela aplacar a força da libido:

Descendo, em meio ao sonho, em silêncio, contidos,

Os leões, da indolência apartam meus vestidos

E contemplam meus pés que amansariam mares.

"Leões" e "mares" são forças poderosas da natureza, forças instintivas primárias, que, em contato com a mulher, se tornam indolentes, mansos.

Resulta dessa atitude um tipo de autismo, de regressão por parte de Herodíade, o que configurará o mito de Narciso, tão caro ao Simbolismo. Quando a Ama lhe pergunta: "para quem (...)/guardarás a riqueza ignorada/E o vão mistério do teu ser?", Herodíade responde: "só para mim". E o narcisismo explícito torna-se implícito nas inúmeras menções à contemplação especular disseminadas pelo texto: "triste flor solitária sem ter outro fim/Que sua sombra n'água vista em atonia"; "e tudo a meu redor vive na idolatria/Do espelho que reflete em sua calma estanque/Herodias de claro olhar de diamante"; "ó espelho/Água fria do tédio em teu quadro gelada".

O gelado, o inerte, o translúcido (nas inúmeras referências às pedrarias frias) acabam por acentuar as imagens de exaustão, de negação de vida que, paradoxalmente, dão à personagem uma aura de imortalidade. Essa imortalidade nasceria de uma espécie de congelamento, na medida em que Herodíade prefere ao calor da sexualidade o abraço frio da esterilidade:

Noite branca de gelo e de neve fatal!

Sóror da solidão, ó irmã imortal,

Meu sonho há de ascender para ti. 
Nesse sentido, o calor é visto como produtor de impureza, enquanto o frio é identificado com a idealidade que, em seu máximo grau de pureza, torna-se vazia, ou seja, não é propriamente identificável, como entende Hugo Friederich: "É uma idealidade sem conteúdo (...), um simples pólo de tensão, hiperbolicamente ambicionado, mais jamais atingido" (1978, p. 48).

A terceira parte, mais leve, porque os versos são hexassílabos e tetrassílabos, dispostos em quadras, tem como única figura João Batista. Sua leveza formal corresponde à leveza do vôo, para que a cabeça cortada, superando a "desavença antiga/Que o corpo a liga", possa libertar-se dos laços terrenos. A morte, portanto, é vista positivamente, numa total subversão do mito bíblico, em vista do fato de que a atuação da Salomé/Herodíade será fundamental para a ascese do Profeta. Em outras palavras, simbolicamente, o degolamento do Precursor significará a superação da materialidade/sexualidade. A idéia de negação da sexualidade no sacrifício de João torna-se muito clara, quando identificamos a cabeça degolada com o pênis:

A cabeça do Batista (...) exige em realidade outra oferenda bem distinta, a víscera genesíaca do homem, suscetível de ser decapitada, que também foi chamada de caput e está idealmente equiparada à víscera capital por uma analogia material - a circuncisão (CANSINO-ASSENS, 1918, p. 53).

Sabe-se que foi João Batista quem instituiu o ritual do batismo com a água, substituindo os ritos priápricos da circuncisão. Herodíade recupera o ritual pagão, para, com ele, paradoxalmente, negar a sexualidade. Assim, através dessa espécie de batismo herético ("Mas levada (a cabeça) ao abismo/Pelo mesmo batismo/Que elegeu minha sina"), consegue fazer que o Profeta se liberte da materialidade. Ora, se se concebe João Batista como duplo de Salomé, o seu animus, não será difícil concluir que o ritual simbolizará a própria libertação da heroína, o seu vôo, a conquista de um absoluto.

Como já foi dito no início do ensaio, a figura de Salomé/Herodíade convergirá emblematicamente para a figura do poeta, ou seja, esse drama tão cheio de perífrases não passa de uma grande perífrase sobre o ato da criação poética. O desejo da heroína, assim, representa aquele anseio órfico do artista de atingir a poesia pura, quando a palavra, "abandonando-se a seus movimentos" (FRIEDRICH, 1978, p. 127), torna-se ela própria realidade. Essa atuação poética de Mallarmé resultaria de um descontentamento com o mundo real, análogo ao descontentamento de Herodíade com a materialidade e/ou sexualidade. O poeta isola-se e abandona os contatos com a realidade e cria espécie de vácuo dentro de si, para onde convergirão as formas ideais, puras abstrações, "a flor ausente de todos os buquês", como dizia o próprio poeta. É por isso que a poesia de Mallarmé termina por cantar o vazio, o nada ("Do meu sonho disperso eu vi toda nudez!", diz Herodíade), pelo fato de que ele não acredita que, para além do mundo real, haja algo plenamente identificável para substituir a materialidade.

Contudo, a intuição da "idealidade vazia" revelará as insuficiências da linguagem empobrecida no uso diário e incapaz de traduzir as revelações, a experiência dessa "nudez", emblema do incrível estado de pureza da palavra. Isso fará que Mallarmé promova a revolução da linguagem poética: o uso constante das alusões, das perífrases, são formas de aliviar as coisas do seu peso. Ao mesmo tempo, subvertendo o mito bíblico, ao retirar-lhe o sentido moral, Mallarmé elevará com sua Salomé/Herodíade um hino à tarefa poética, única maneira, a seu ver, de atingir o real absoluto. $\mathbf{c}^{\mathbf{g}}$ 


\section{REFERÊNCIAS BIBLIOGRÁFICAS:}

BÍBLIA SAGRADA. Edição revista e corrigida. Tradução de João Ferreira de Almeida. São Paulo: Sociedade Bíblica do Brasil, 1995.

CAMPOS, Augusto de. Linguaviagem, São Paulo: Companhia das Letras, 1987.

CANSINO-ASSENS, R. Salomé em la literatura. Madrid: Editorial América, 1918, p. 81.

FRIEDRICH, Hugo. Estrutura da lírica moderna. Tradução Dora Ferreira da Silva. São Paulo: Duas Cidades, 1978.

GOMES, Álvaro Cardoso. A estética simbolista, 2a ed., São Paulo: Atlas, 1994. A poética do indizivel. São Paulo: Unimarco, 2001.

HUSSERL, Edmund. The phenomenology of internal time-consciousness. Bloomington: Indiana University Press, 1964.

PESSOA, Fernando. Obra poética. Rio de Janeiro: Aguilar, 1965. 